\title{
Thirty years of marine ecotoxicological studies at the TNO Laboratory for Applied Marine Research, Den Helder (The Netherlands)
}

\author{
M. C. Th. Scholten \\ TNO Laboratory for Applied Marine Research, Institute of Environmental Sciences, \\ Dept. of Biology; P. O. Box 57, 1780 AB Den Helder, The Netherlands
}

\begin{abstract}
This paper reviews the development of marine field ecotoxicology at the TNO Laboratory for Applied Marine Research. The scope of research, including biological monitoring with mussels, mesocosm studies and ecological risk analysis, is described. Some highlights from an historical point of view are given, with as yet unpublished data presented as examples.
\end{abstract}

\section{INTRODUCTION}

In 1954, the independent Netherlands Organization for Applied Scientific Research (TNO) founded a laboratory for marine field studies in Den Helder. Initially, the scope of the TNO Laboratory of Applied Marine Research was focussed on technological materials research, but, over time, the Laboratory became more and more a marine biological field station. The biological research is directed towards solving practical problems for governmental and industrial bodies. Most of the results are published in technical reports (more than 300 since 1971) rather than in scientific papers. This paper is meant to (re)introduce the marine biological work of the Laboratory over the last three decades to the scientific community of marine biologists.

\section{FROM FOULING BIOLOGY TOWARDS ECOTOXICOLOGY}

One of the linking factors between technological and biological marine research was, and is, the technological prevention of biological fouling of materials in the sea. The Laboratory started biological studies with barnacles and mussels, the main point of interest being the biological mechanism of fouling in order to optimize chemical antifouling systems (De Wolf, 1964a; De Wolf \& Van Londen, 1966; De Wolf, 1964b, 1973). The notification of marine pollution problems gradually changed the direction of the biologists towards ecotoxicological field studies, enhanced by a strong recession in the European shipping industry and the related anti-fouling paint industry. Biological research related to the chemical pollution of the North and Wadden Seas was initiated in 1964. An incidental release of copper into Dutch coastal waters in April 1965, resulting in mass fish mortalities, was the last straw. The step from the mechanisms of copper- 
inhibited fouling to copper-induced toxicology is from a biological standpoint a small one...

The marine biologists at TNO started their ecotoxicological research in the laboratory with fouling organisms (mussels and barnacles) in the '60s, when few had even heard of "ecotoxicology". In 1970, the unique step towards ecotoxicological field studies was undertaken.

\section{WATER QUALITY MONITORING WITH MUSSELS}

The mussel (Mytilus edulis) appeared to be a suitable species for field studies related to marine pollution. Mussels experience water pollution directly, while filtering water for their food and oxygen supply. Contaminants are accumulated in their tissues in concentrations that directly reflect the average concentrations in the surrounding water, and thus the water quality at a certain location. This is not restricted to persistent toxicants such as trace metals, but is also valid for organic toxicants such as oil compounds, due to the low metabolization capacity of mussels. Mussels are easy to handle, and there is sufficient knowledge of their biology to enable a variety of toxic effects to be identified.

After a preliminary investigation of the metal content of mussels from Dutch coastal waters (De Wolf \& Lewis, 1972), mussels were collected along the entire westernEuropean coast for determination of the tissue concentrations of mercury (Fig. 1). This was done at the request of the Belgian mussel consumers association.

In 1971 and 1972, the TNO biologists built watertight wooden caissons to enclose replicate parts of a natural intertidal mussel bed in the Wadden Sea for experimental field studies on the bioaccumulation and related effects of mercury and copper (De Wolf et al., 1972; De Kock \& Kuiper, 1981). From these experiments, internal lethal effect concentrations of 5-9 $\mathrm{mg} \mathrm{Hg} / \mathrm{kg}$ AFDW (Ash Free Dry Weight) and $40-50 \mathrm{mg} \mathrm{Cu} / \mathrm{kg}$ AFDW were established for mussels (unpubl. data).

Since 1974, the bioaccumulation field studies with mussels have been standardized, following the principle of Active Biological Monitoring ( $A B M$ ). In such $A B M$ surveys (De Kock, 1986), selected mussels of a certain length class are collected from a relatively unpolluted standard stock. The organisms are divided at random into similar groups, and these samples are transplanted in cages to selected monitoring locations (Fig. 2). After a certain exposure period (4-8 weeks) the samples of organisms are re-collected and the bioaccumulation levels of pre-selected chemicals are determined. Advantages of this

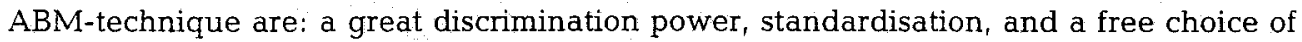
monitoring locations. In 1979-1980, TNO explored the possibilities for a strategic monitoring network by transplanting caged mussels from the then pristine Irish Atlantic coast, to 20 locations in Dutch coastal waters (De Kock, 1983; see Fig. 3). Only in 1989 did the Dutch government (Rijkswaterstaat) ask TNO to proceed on this initiative and to set up a regular $A B M$ network of 16 locations (Fig. 3) along the Dutch coast. At every location, mussels are exposed three times a year, in order to determine trends of bioaccumulated chemicals over time. Since 1992, Rijkswaterstaat has carried out the ABM-programme by itself.

Homogenates from all mussel tissues collected by TNO since 1971 are kept deepfrozen in a specimen bank, for retrospective studies. For example, the decrease of the PCB concentrations in Dutch coastal waters was first determined in the early '80s for 


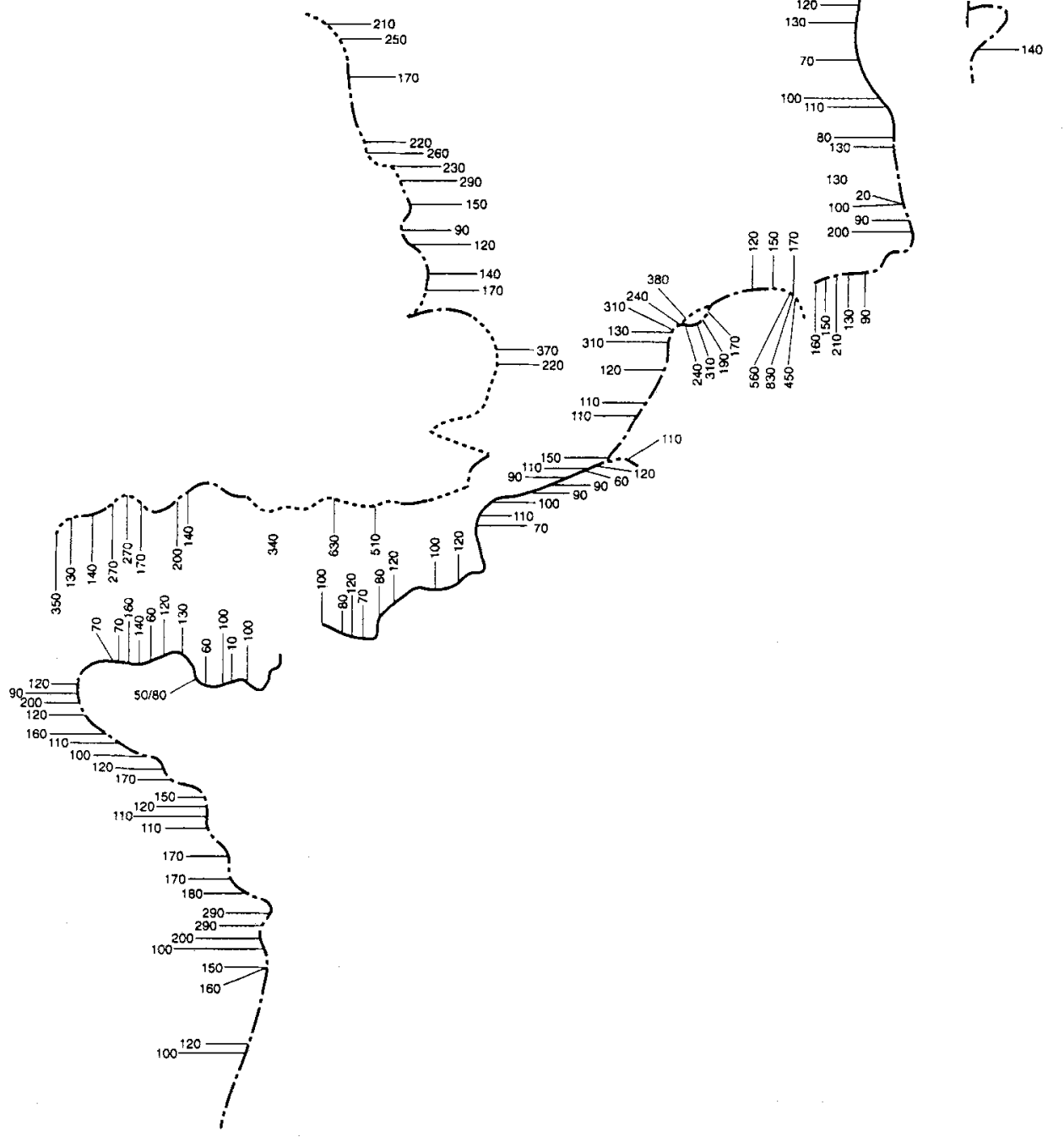

Fig. 1. The mercury concentration in mussels $\left(\mu \mathrm{g} / \mathrm{kg}^{-1} \mathrm{WW}\right)$ collected at indicated locations along the northwestern European coast in 1972 (after De Wolf, internal technical report, 1972)

ABM mussels exposed at similar locations in 1974 and 1980 , using specimenbank samples in simultaneous analysis (Pries et al., 1984). Retrospective analysis of mussels collected along the Dutch coast between 1971 and 1987, with accurate analytical GCmethods that only became available in the late ' 80 s, confirmed this trend (Table 1).

Over the years, the ABM has proven to be a valuable method in several field surveys, with respect to the monitoring of contaminants' distribution (e.g. Fig. 4), determination of 


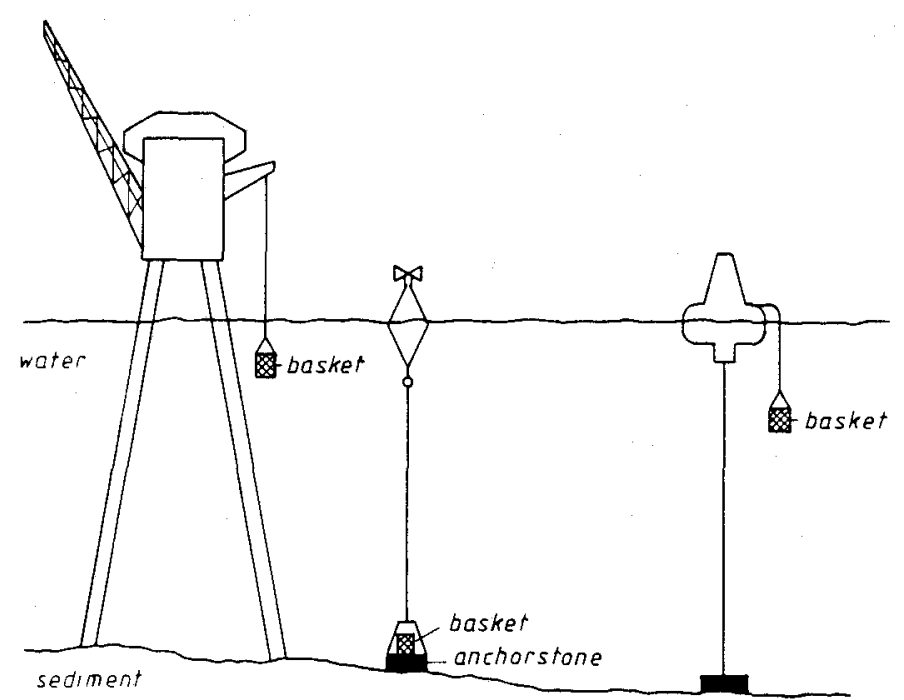

Fig. 2. Exposure of caged mussels in Active Biological Monitoring surveys. Cages were suspended in sea water, attached to buoys or other offshore constructions, or sunk to the seabed by means of an anchorstone (after van het Groenewoud, internal technical report, 1988)

bio-concentration factors in the field (e.g. Fig. 5), the mechanisms behind variations in bio-availability of contaminants, and measurements of stress indicating effect parameters.

An example of a bioavailability study, is the field verification of the complexion of metals in the marine environment (Kramer, 1986a, b) during the period of algal blooms in Dutch coastal waters (van Eck et al., 1989).

A variety of effect parameters were evaluated by examination of mussels from ABM surveys, especially with respect to energy-budget studies (Scope for Growth, SFG). From a series of field studies, it was concluded that the discrimination power of the SFGmethod was generally too low to determine pollution stress in the marine environment as a result of variations in other stress factors, except for strong pollution gradients correlated with other environmental conditions (e.g. Scheldt estuary) or under similar experimental conditions (e.g. small-scale mesocosm studies). The method failed to detect pollution gradients during the marine disposal of dredged materials or oil-based muds, whereas bioaccumulation data were clearly able to show pollution gradients (Scholten, unpubl. data).

Histopathological screening of the tissues of ABM-mussels has shown more promise as a method for the detection, identification and specification of pollution gradients (Bowmer et al., 1991, for freshwater mussels; unpubl. data for marine mussels).

"Mussel monitoring" also helped initiate the development of an Early: Warning System (EWS) for water pollution. The automatic registration of the valve movement of mussels, by means of an electromagnetic field induced by coils at both valves of a mussel, is based on the fact that mussels close their shells under environmental stress (Kramer et al., 1989). A free-standing EWS-device, recording the behaviour of 8 mussels, is now available (Kramer \& Botterweg, 1991). 


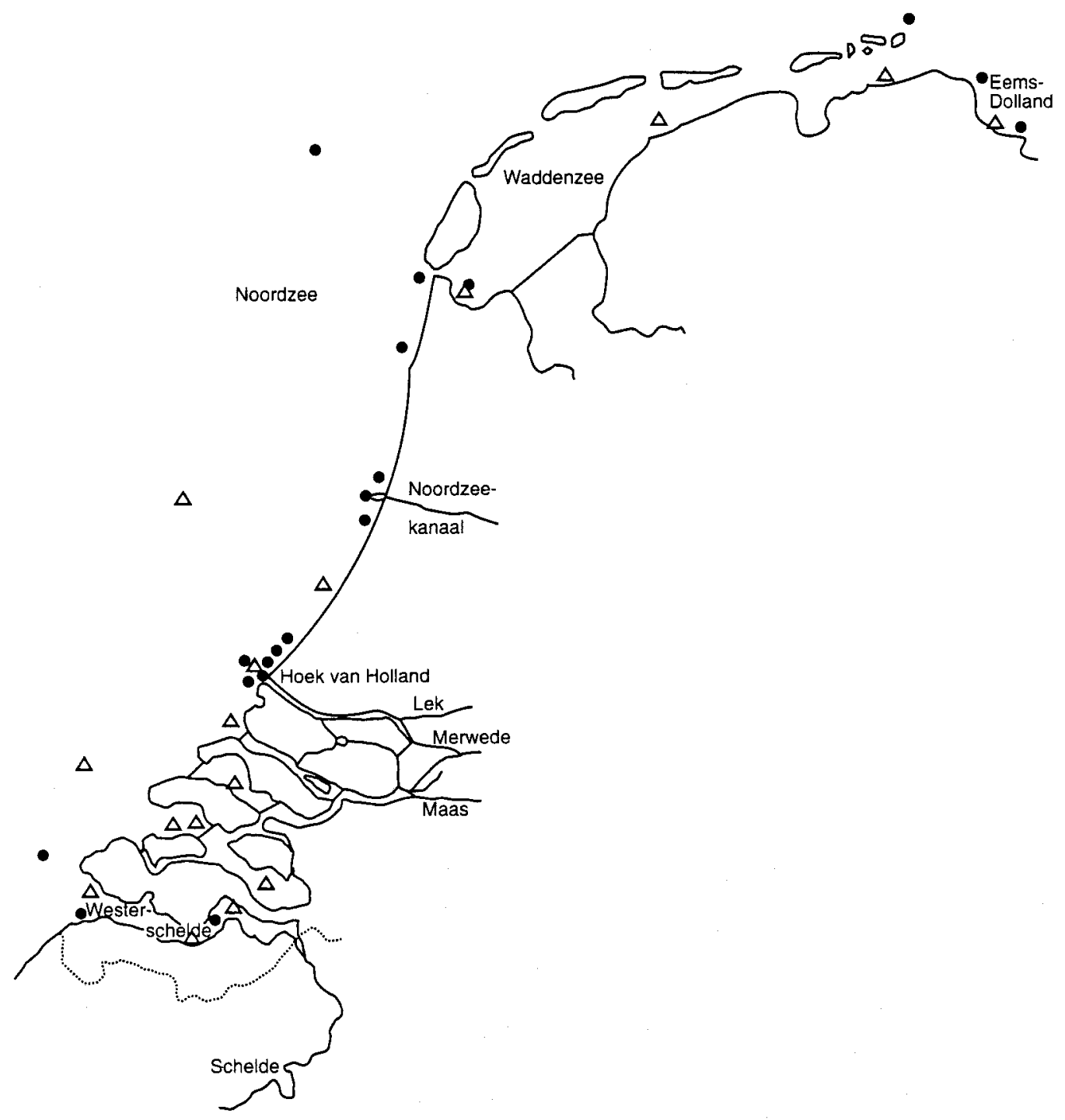

Fig. 3. The Active Biological Monitoring locations of the preliminary network (๑) of TNO in 1979/80 and the final network $(\Delta)$ designed for Rijkswaterstaat, since 1989 (after de Kock \& Marquenie, technical report, 1980, and het Groenewoud \& Scholten, internal technical report, 1990)

\section{MESOCOSM STUDIES}

The initial studies featuring the enclosure of mussel banks for heavy-metal research triggered the idea of ecotoxicological experimentation with organisms from the field in large-scale outdoor systems, the so-called experimental ecosystems or mesocosms. Mesocosm experimentation allows the study of effects of contaminants on organisms or communities over longer periods (months/years) under simulated (but identical and 
Table 1. The overall PCB concentration ( $\Sigma$ PCB-congeners $15,28,52,49,44,70,101,87,153,138$, $180 ; \mathrm{mg} / \mathrm{kg} \mathrm{AFDW})$ in mussels $(\mathrm{n}=100)$ collected at 3 stations along the Dutch coast in 1971, 1980 and 1987. The mussels were stored in the specimen bank prior to analysis in 1988 (after Scholten, technical report, 1988)

\begin{tabular}{|lcccc|}
\hline & & 1971 & 1980 & 1987 \\
\hline Scheveningen & (S. Holland) & 3.81 & 2.12 & 0.71 \\
IJmuiden & (M. Holland) & 1.97 & 1.10 & 0.56 \\
Petten & (N. Holland) & 1.53 & 0.92 & 0.33 \\
\hline
\end{tabular}

controlled) natural conditions. The results of these studies are used for "field" validation of laboratory toxicity tests (De Kock \& Kuiper, 1981; Adema et al., 1983), for the verification of (calculated) chemical standards and norms, and for the explanation of field observations.

\section{Experimental plankton systems}

The first type of mesocosm, used since 1974, was an experimental plankton system. This is a plastic bag with a depth of ca $3 \mathrm{~m}$ filled with ca 1500 litres of natural seawater,

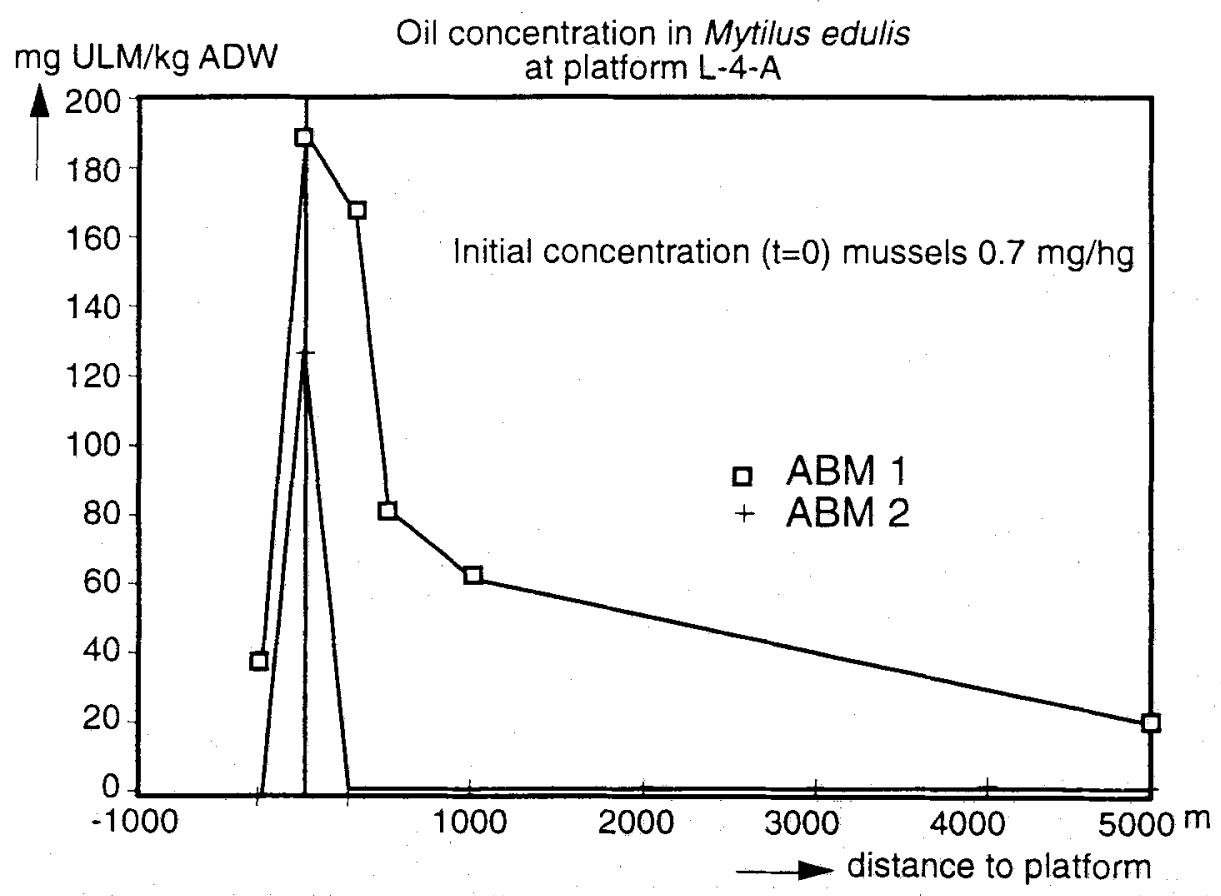

Fig, 4. The concentration of oil in tissues of mussels (Mytilus edulis) exposed in an ABM-survey at several distances from an offshore drilling platform (L-4-A) during the drilling (ABM 1), and two months later (ABM 2). Note that observable release of oil from the sediments after disposal of oil polluted drill cuttings is restricted to the discharge point (after van het Groenewoud, internal technical report, 1988) 


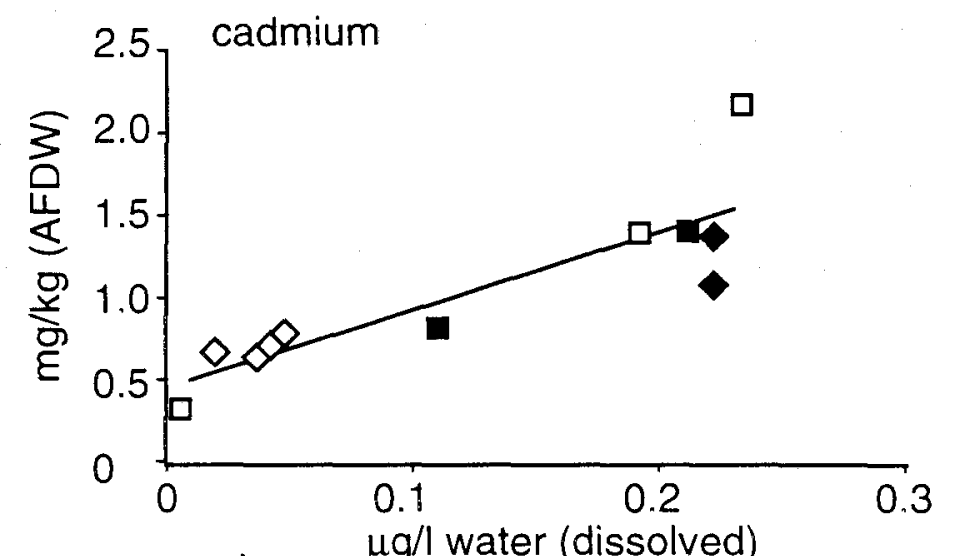

\begin{tabular}{l}
\hline ABM89a \\
ABM89b \\
ABM90 \\
$\diamond$ ABM86 \\
\hline
\end{tabular}
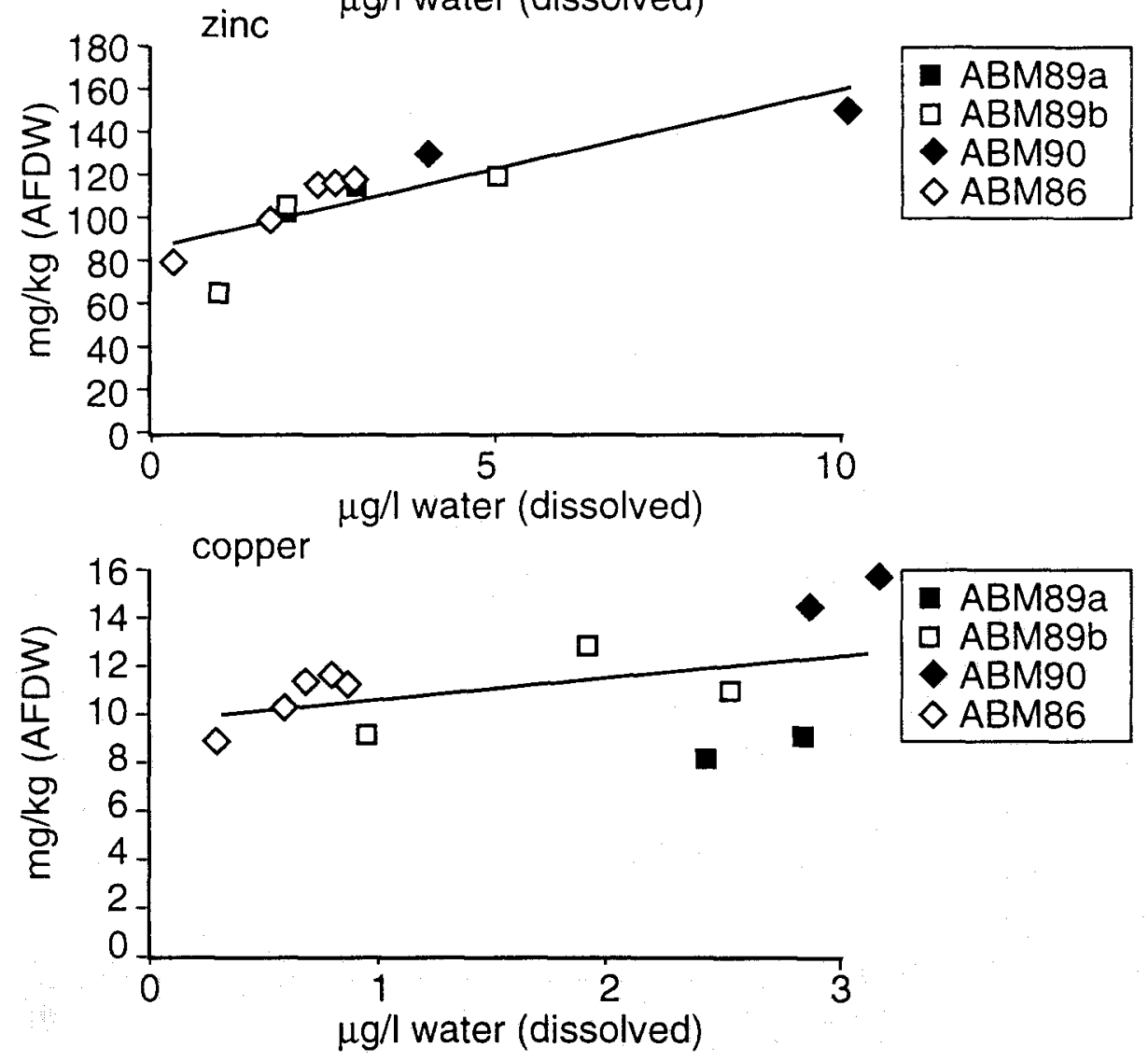

Fig. 5. The bioaccumulation factor of metals (cadmium, zinc and copper) for mussels in the field situation, derived from several ABM-studies with simultaneous water analysis (after Scholten, Jak \& Kramer, internal technical report, 1991) 
including plankton. The bag is suspended in the sea. A series of simultaneously filled plankton systems appeared to develop very similarly, indicating small differences between bags (Kuiper, 1977a). In a series of 24 ecotoxicological experiments, the fate and effects of various contaminants (e.g. $\mathrm{Hg}, \mathrm{Cd}, \mathrm{Cu}$, phenols, dichloroaniline and crude oils combined with dispersants) on the plankton were observed (Kuiper, 1977b; Kuiper, 1981a, b; Kuiper et al., 1983; Kuiper, 1984; Kuiper \& Hanstveit, 1984a, b; Scholten \& Kuiper, 1987, and much unpublished data). Compared to laboratory toxicity tests, the biodegradation of organic compounds was generally lower in the plankton systems, probably due to competition for nutrients between bacteria and phytoplankton (Kuiper, 1982). The effect concentrations were relatively low compared to laboratory tests, probably due to the sensitivity of copepods (Jak, unpubl. data).

An important finding was the induction of microalgae (viz. Haptophycea)-blooms, due to a reduced control of algal biomass by zooplankton as a result of inhibited reproduction in copepods. In an experiment with a relatively low exposure of the plankton systems to PCB's (resulting in PCB concentrations in water comparable to those in the coastal waters of the North Sea during the ' 70 s and early ' $80 \mathrm{~s}$ ), the reduced production of eggs by Acartia clausi (Fig. 6) finally resulted in an uncontrolled bloom of Phaeocystis sp. that did not appear in the unpolluted control systems, despite similar conditions with respect to nutrients.

Recently, the experimental plankton systems were used to explain shifts in zooplank-

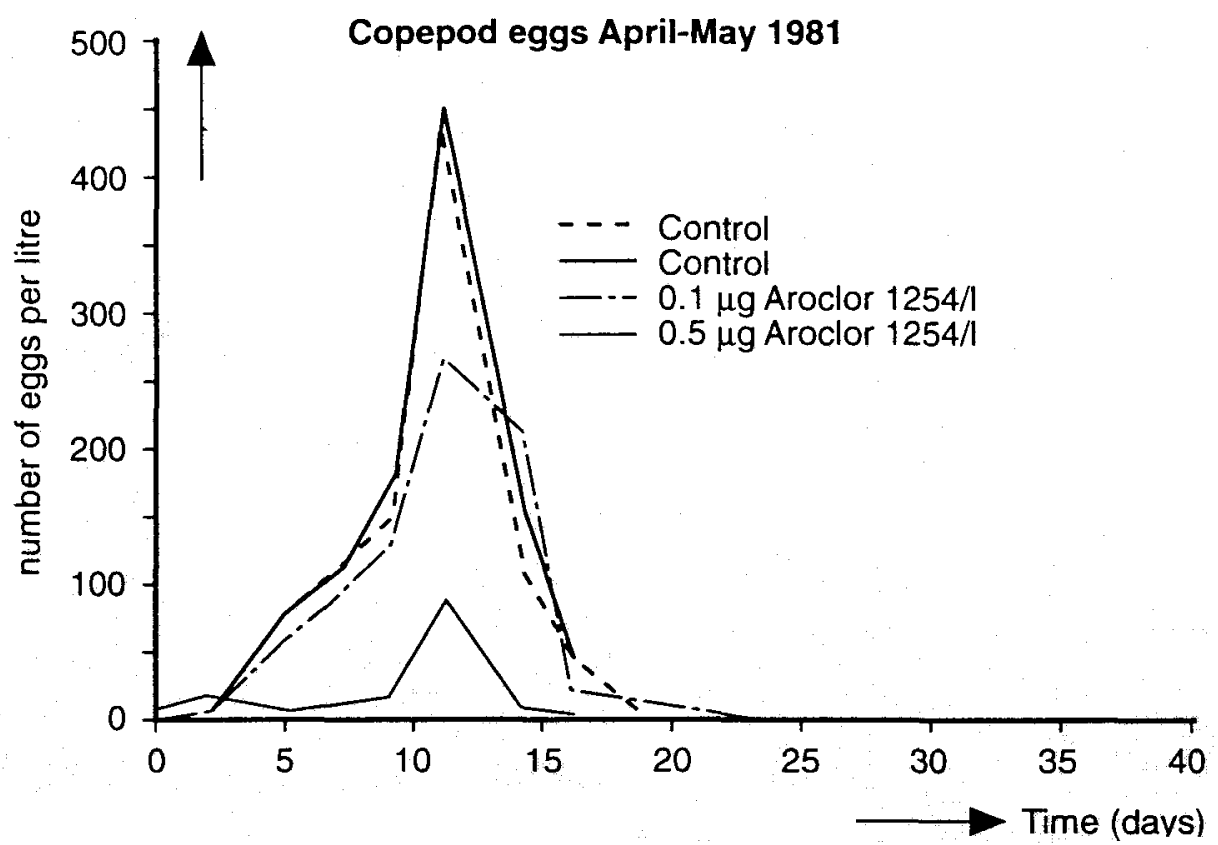

Fig. 6. The density of copepod eggs in experimental plankton systems during a study on the fate and effect of PCBs. The actual concentrations were, respectively, $0,0.1$ and $0.5 \mu \mathrm{g}$ PCB/l. The integral density is reduced by $25 \%$ and $85 \%$, respectively, at the lower and higher polluted situation (after Kuiper, internal technical report, 1981) 
ton community structure and related efficacy of phytoplankton control (Jak, unpubl. data) and to investigate which factors control the release of dimethylsulfide, produced by marine plankton, into the atmosphere, where it contributes to climatic changes by cloud formation (Kwint et al., 1993).

\section{Bioassays with benthic invertebrates}

Most of the persistent contaminants (e.g. metals, organochlorines, PAHs) finally accumulate in sediments. Depending on their bioavailability - influenced by mineralisation of organic matter or changes in the redoxpotential of sediments - these contaminants may cause a chronic exposure of benthic biota to toxicants.

Mesocosm scale bioassays with benthic biota allow for an assessment of the bioavailability and related toxicity of sediment-bound contaminants under various environmental conditions (Marquenie et al., 1983; Marquenie 1985; Marquenie et al., 1985a, b; Bowmer \& Scholten, 1990; Jenner \& Bowmer, 1990, 1992). In a series of bioassays of light to moderately polluted sediments with benthic invertebrates from the Wadden Sea area, carried out since 1983, it appeared that the lugworm (Arenicola marina), the Baltic tellin (Macoma balthica) and the edible cockle (Cerastoderma edule) are the best indicator species representing deposit feeding (sediment resp. sediment surface) and filter-feeding organisms. Seasonal variation is important in the interpretation of lugworm bioaccumulation. An increase of the contaminant concentration in the lugworm during the summer and a sudden decrease in September-October (Fig. 7) is related to the production and spawning of gametes (viz. lipid rich eggs). The magnification of the contaminant concentration in eggs compared to tissues (Fig. 8) is the basis for in vitro-fertilization studies, with eggs obtained from lugworms that have been exposed to such polluted sediments in mesocosms or in the field (Kaag, unpubl. data). Similar reproduction studies are undertaken with the other two selected test species.

Since 1991, field and mesocosm studies have been initiated to select appropriate species, representative of the offshore North Sea benthos, for use in mesocosm experimentation. A final selection has not yet been made, but the masked crab (Corystes cassivelaunus) has already been identified as a suitable species for bioaccumulation studies (e.g. Fig. 9), with potential for reproduction toxicity studies with eggs that magnify contaminants.

\section{Experimental coastal ecosystems}

Mesocosms not only provide a tool for modern ecotoxicological tests with individuals of test species under realistic conditions, but also for ecotoxicological studies on the fate of contaminants and related effects on the dynamics of populations and species interactions. In larger scale mesocosms, more-or-less complete communities of organisms representing the lower trophic levels can be studied (De Kock \& Kuiper, 1981). Only large predators have to be excluded. Such mesocosm studies provide long and integral measurement series of interactive ecological parameters, permitting ecosystem analysis with the help of statistical techniques or mathematical models.

Since 1981, experimental tidal flats ( 8 replicates of $21 \mathrm{~m}^{2}$ each) have been used for oil-pollution studies (only preliminary results published by Kuiper et al., 1984), oil-spill 

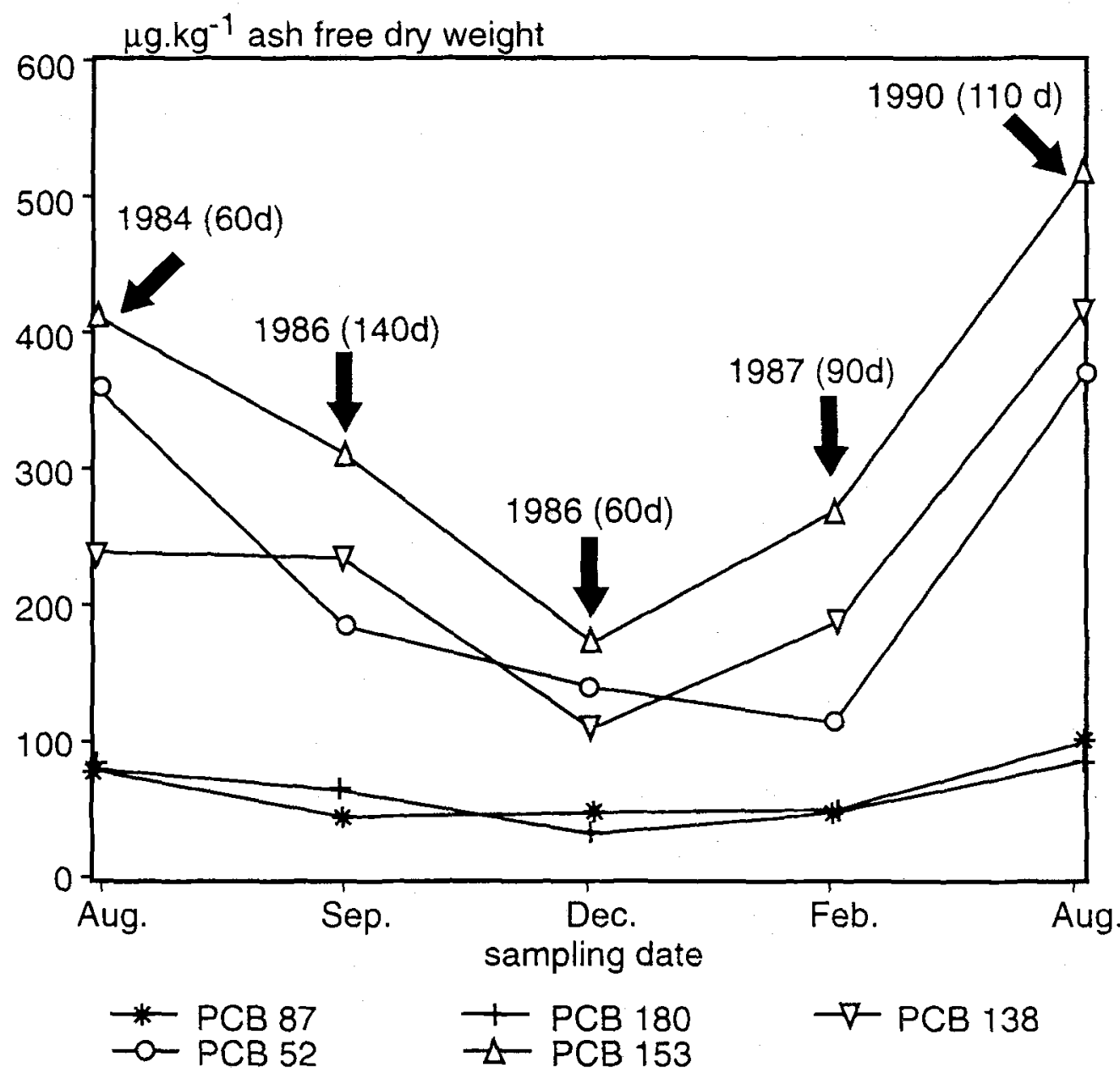

Fig. 7. The seasonal variation in the concentration of PCB-congeners ( $\mu \mathrm{g} / \mathrm{kg}$ AFDW) of lugworms exposed to a typical Rotterdam harbour (Botlek) sediment in five bioassays in different seasons (after Bowmer \& Marquenie, internal technical report, 1991)

combatment studies, and studies on the ecological impacts of marine disposal of dredged materials, mussel cultivation and eutrophication.

Within the whole realm of responses, some indicative parameters have been detected. Pollution primarily affects zooplankton dynamics, interspecific relations between small benthic fauna species (viz. nematode species; Corophium, Hydrobia) and reproductive success of benthic macrofauna.

Since 1989, experimental salt marsh systems $\left(3\right.$ replicates of $75 \mathrm{~m}^{2}$ each; Leendertse et al., 1992) have been used for studies on the fate of compounds (macroelements and contaminants) sedimenting in a lower-salt marsh, in order to establish whether saltmarshes can act as a sink for those compounds without becoming a new source. Smallerscale mesocosms have been used for oil-pollution studies with salt-marsh plant communities (Scholten \& Leendertse, 1991). 


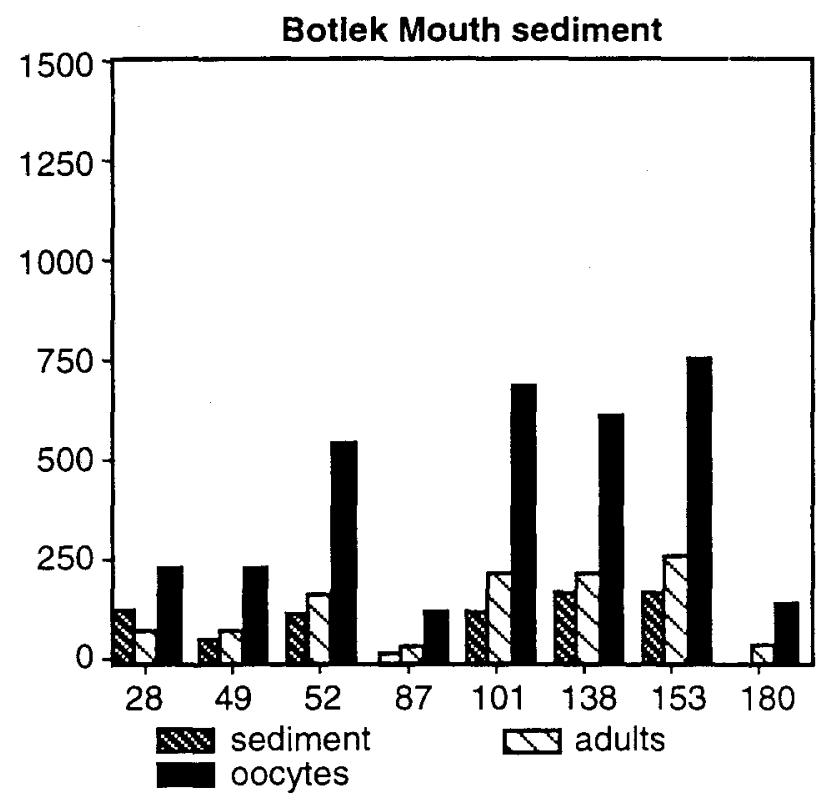

Fig. 8. The accumulation of PCB-congeners in tissues and eggs of lugworms exposed to a polluted Rotterdam harbour (Botlek) sediment. All concentrations in $\mu \mathrm{g} / \mathrm{kg}$ AFDW. Note the biomagnification of PCBs in eggs, compared to tissues (after Bowmer et al., internal technical report, 1991)

$B(a) P$ in tissue

$0.5 \% \mathrm{C} \square 3.0 \% \mathrm{C}$

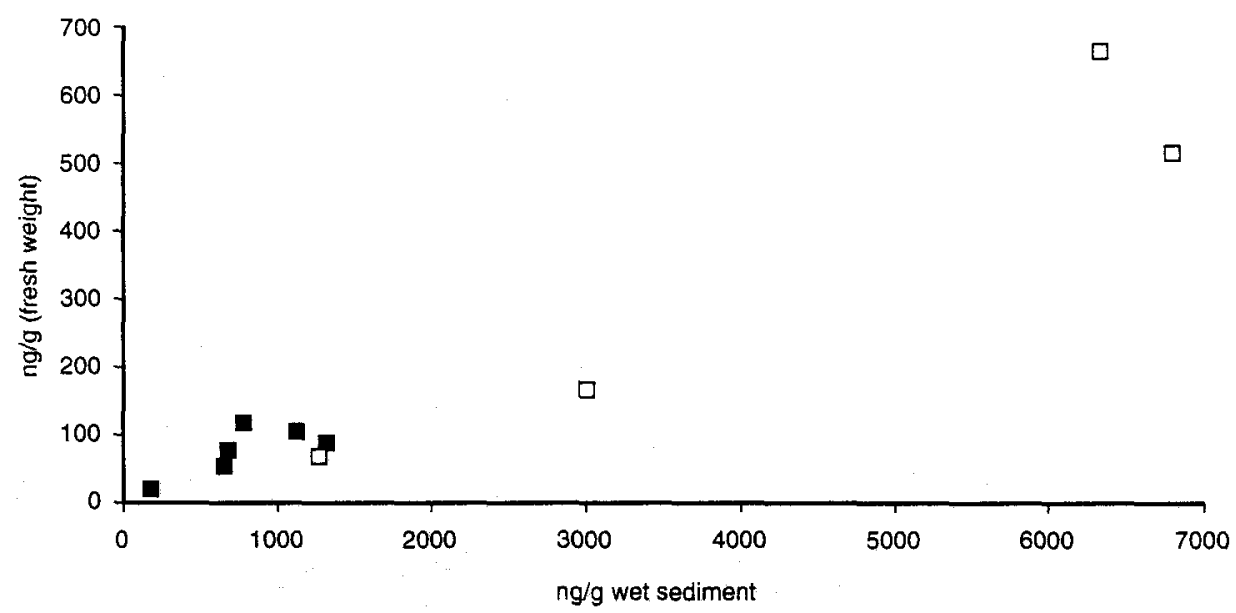

Fig. 9. The accumulation of Benzo(a)pyrene in the masked crab exposed to sediments with various Bap-concentrations and two levels of organic content $(0.5$ and $3 \% \mathrm{DW})$. Note the insignificance of organic matter content in determining the bioaccumulation (after van het Groenewoud et al., internal technical report, 1992) 


\section{ECOLOGICAL RISK ANALYSIS}

Current trends in environmental policy are directed towards the sustainable development of the marine environment, within the carrying capacity of marine ecosystems. Answering the increasing number of questions related to the assessment of ecological effects of pollution caused by human activities can only exceptionally be based on the results of one particular experiment or field survey. In most cases, various sources of ecotoxicological and ecological data have to be used. For this purpose, ecotoxicological and biological data of marine organisms are stored in the database MARITOX in order to permit the necessary data-analysis.

The basic principle of ecological risk analysis is the comparison of the level of exposure to environmental disturbances with a threshold level indicating the sensitivity of biota to these disturbances. Some variants regarding a probabilistic or site-specific marine ecological risk analysis have been developed by the laboratory (Turkstra et al., 1991; Schobben et al., 1992; Schobben \& Scholten, 1993).

It should be noted that, for a realistic ecological risk analysis of contamination, ecotoxicological data obtained from laboratory studies needs to be adjusted for the ambient field situation concerned. This adjustment is based on environmental conditions, exposure time, and life-stage. Moreover, a biologically sound translation of data from test species to local sentinel species is needed.

Parallel with the assessment of the toxicity of contaminants on the basis of chemical properties (QSAR), marine biological knowledge can be used for the assessment of the sensitivity of species to contaminants on the basis of biological properties (QSSR: Quantitative Species Susceptibility Relationships).

\section{FROM ECOTOXICOLOGY BACK TO ANTI-FOULING RESEARCH}

Biological research at TNO never became free from the issue of anti-fouling. In the ' 80 s several mesocosm experiments were carried out for the assessment of the release of biocides (viz. tributyltin) from paints and consequent ecotoxicological effects under field conditions (Bowmer \& Ferrari, 1989).

Nowadays, research is being directed towards alternative anti-fouling compounds based on the natural anti-fouling mechanisms of marine biota. There is experimental evidence that secondary metabolites produced by sponges can prevent objects from fouling (Willemse \& Ferrari, 1993).

\section{CONCLUSION}

The TNO Laboratory for Applied Marine Research has extensive experience in applied marine biology, especially in ecotoxicological field studies. Although most of the results are published in technical reports, it contributes to the development of the fundamental marine biological science, to which it is closely related.

Acknowledgements. As the present head of the biological part of TNO Laboratory for Applied Marine Research, I have presented the scope of our research (including some as yet unpublished results) over the past 30 years. The research is the result of cooperative teamwork. Therefore I will confine myself to mentioning the most important "team-members" who, during the last 20 years, 
produced the work and data presented in this paper: my predecessors Piet de Wolf* and Pim de Kock; the leading scientists Jan Kuiper*, Joop Marquenie*, Kees Kramer and Tim Bowmer*; the new generation, Henk Schobben, Robbert Jak, Edwin Foekema and Klaas Kaag; and the essential research workers, Henk van het Groenewoud, Piet Roele, Ben Schrieken*, Wilma Lewis*, Gerrit Hoornsman, Marijke van der Meer, Marie-Cécile Scholten, Liesbeth van der Vlies and Rik Kwint. (Those marked with ${ }^{*}$ are no longer working in the Laboratory.) The English text was corrected by Màira Bowmer.

\section{LITERATURE CITED}

Adema, D. M. M., Kuiper, J., Hanstveit, A. O. \& Canton, H. H., 1983. Consecutive system of tests for assessment of the effects of chemical agents in the aquatic environment. In: IUPAC pesticide chemistry: human welfare and the environment. Ed. by J. Miyamoto. Pergamon Press, Oxford, $537-544$

Bowmer, C. T. \& Ferrari, G., 1989. A new approach to the development and testing of antifouling paints. - J. Oil Colour Chem. Ass. 10, 391-396.

Bowmer, C. T. \& Scholten, M. C. Th., 1990. The environmental evaluation of harbour dredged sediments. In: Contaminated soil '90. Ed. by F. Arendt, M. Hinsenveld \& W. J. van den Brink. Kluwer, Dordrecht, 1355-1362.

Bowmer, C. T., Meer, M. van der \& Scholten, M. C. Th., 1991. A histopathological analysis of wild and transplanted Dreissena polymorpha from the Dutch sector of the river Maas. - Comp. Biochem. Physiol. 100C, 225-229.

Eck, B. Th. M. van, Kramer, K. J. M., Kerdijk, H. N. \& Pagee, H. van, 1989. Trace metals in Dutch coastal waters: speciation and bioaccumulation by mussels. In: Proceedings of the International Conference on Heavy Metals in the Environment, Geneva. Ed. by J.-P. Vernet. CEP Consultants, Edinburgh, 210-213.

Jenner, H. A. \& Bowmer, T., 1990. The accumulation of metals and their toxicity in the marine intertidal invertebrates Cerastoderma edule, Macoma balthica, Arenicola marine exposed to pulverised fuel ash in mesocosms. - Environ. Pollut. 66, 139-156.

Jenner, H. A. \& Bowmer, T., 1992. The accumulation of metals and toxic effects in Nereis virens exposed to pulverised fuel ash. - Environ. Monit. Assess. 21, 85-98.

Kock, W. Chr. de, 1983. Accumulation of cadmium and polychlorinated biphenyls by Mytilus edulis transplanted from pristine water into pollution gradients. - Can. J. Fish. aquat. Sci. 40, 282-294.

Kock, W. Chr. de, 1986. Monitoring bio-available marine contaminants with mussels (Mytilus edulis L.) in the Netherlands. - Environ. Monit. Assess. 7, 209-220.

Kock, W. Chr. de \& Kuiper, J., 1981. Possibilities for marine pollution research at the ecosystem level. - Chemosphere 10,575-603.

Kramer, K. J. M., 1986a. Apparent copper complexation capacity and conditional stability constants in North Atlantic waters. - Mar. Chem. 18, 335-349.

Kramer, K. J. M., 1986b. On the copper complexation capacity in the marine environment. Thesis, Univ. Groningen, $133 \mathrm{pp}$.

Kramer, K. J. M. \& Botterweg, J., 1991. Aquatic biological early warning systems: an overview. In: Bioindicators and environmental management. Ed. by. D. W. Jeffrey \& B. Madden. Acad. Press, London, 95-126.

Kramer, K. J. M., Jenner, H. A. \& Zwart, D. de, 1989. The valve movement response of mussels: a tool in biological monitoring. - Hydrobiologia 188/189, 433-443.

Kuiper, J., 1977a. Development of North Sea coastal plankton communities in separate plastic bags under identical conditions. - Mar. Biol. 44, 97-107.

Kuiper, J., $1977 \mathrm{~b}$. An experimental approach in studying the influence of mercury on a North Sea coastal plankton community. - Helgoländer wiss. Meeresunters. 30, 652-665.

Kuiper, J., 1981a. Fate and effects of mercury in marine plankton communities in experimental enclosures. - Ecotoxicol. environ. Saf. 5, 106-134.

Kuiper, J., 1981b. Fate and effects of cadmium in marine plankton communities in experimental enclosures. - Mar. Ecol. Prog. Ser. 6, 161-174.

Kuiper, J,, 1982. The use of enclosed plankton communities in aquatic ecotoxicology. Thesis, Univ. Wageningen, 53 pp. 
Kuiper, J., 1984. Fate and effects of 5-nitrofuroic acid-2 (NFA) on a marine plankton community in experimental enclosures. In: Aquatic toxicology and hazard assessment. Ed. by W. E. Bishop, R. D. Cardwell \& B. B. Heidolph. American Society for Testing and Materials, Philadelphia, 171-179.

Kuiper, J. \& Hanstveit, A. O., 1984a. Fate and effects of 4-chlorophenol and 2,4-dichlorophenol in marine plankton communities in experimental enclosures. - Ecotoxicol environ. Saf, 8, 15-33.

Kuiper, J. \& Hansveit, A. O., 1984b. Fate and effects of 3,4-dichloroaniline (DCA) in marine plankton communities in experimental enclosures. - Ecotoxicol. environ. Saf. 8, 34-54.

Kuiper, J., Brockmann, U. H., Groenewoud, H. van het, Hoornsman, G. \& Roele, P., 1983. Effects of mercury on enclosed plankton communities in the Rosfjord during POSER. - Mar. Ecol. Prog. Ser. 14, 93-105.

Kuiper, J., Wilde, P. de \& Wolff, W., 1984. Effects of an oil spill in outdoor model tidal flat ecosystems. Mar. Pollut. Bull. 15, 102-106.

Kwint, R. L. J., Kramer, K. J. M., Baart, A. C. \& Verhagen, H. L. M., 1993. The production of DMS by a plankton community: a mesocosm experiment. In: Dimethylsulphide: oceans, atmosphere and climate. Ed. by G. Restelli \& G. Angeletti. Kluwer, Dordrecht, 53-62.

Leendertse, P. C., Wal, J. T. van der, Asjes, J. \& Jak, P., 1992. Fate and effect of nutrients and contaminants in salt marsh ecosystems: a mesocosm study. - Neth. Inst. Sea Res. Publ. Ser. 20, 269.

Marquenie, J. M., 1985. Bioavailability of micropollutants, - Environ. Technol. Lett. 6, 351-358.

Marquenie, J. M., Kock, W. Chr, de \& Dineen, D. M., 1983. Bioavailability of heavy metals in sediments. In: Proceedings of the International Conference on Heavy Metals in the Environment, Heidelberg. CEP Consultants, Edingburgh, 944-947.

Marquenie, J. M., Simmers, J. W. \& Birnbaum, E., 1985a. The biological fate of heavy metals after aquatic disposal of dredged materials. In: Proceedings of the International Conference on Heavy Metals in the Environment, Athens. Ed. by T. D. Lekkas. CEP Consultants, Edinburgh.

Marquenie, J. M., Jong, P. de \& Schrieken, B., 1985b. Variations in the chemical speciation of heavy metals reflected by mussels. In: Proceedings of the International Conference on Heavy Metals in the Environment, Athens. Ed. by T. D. Lekkas. CEP Consultants, Edinburgh, 673-675.

Pries, C., Kock, W. Chr. de \& Marquenie, J. M., 1984. Specimen banks and the monitoring of surface water pollution by aquatic organisms. In: Environmental specimen banking and monitoring. Ed. by R. A. Lewis. Nijhoff, The Hague, 88-94.

Schobben, H. P. M. \& Scholten, M. C. Th., 1993. Probabilistic methods for marine ecological risk assessment. - ICES J. mar. Sci. 50, 349-358.

Schobben, H. P. M., Schoiten, M. C. Th. \& Asjes, J., 1992. The ecological risk-evaluation technique "REFEREE" applied to pollution problems in the Wadden Sea. - Neth. Inst. Sea Res. Publ. Ser. $20,215-220$.

Scholten, M. \& Kuiper, J., 1987. The effects of oil and chemically dispersed oil on natural phytoplankton communities. - Proc. Oil Spill Conf. 1987, 255-257.

Scholten, M. C. T. \& Leendertse, P. C., 1991. The impact of oil pollution on salt marsh vegetation. In: Ecological responses to environmental stresses. Ed. by J. Rozema \& J. A. C. Verkleij. Junk Publishers, Dordrecht, 184-190.

Turkstra, E., Scholten, M. C. Th., Bowmer, C. T. \& Scholten, H. P. M., 1991. A comparison of the ecological risks from fisheries and pollution to the North Sea biota. - Wat. Sci. Technol. 24, $147-153$.

Willemse, P. R. \& Ferrari, G. M., 1993. The use of antifouling compounds from sponges in antifouling paints. - Surf. Coat. int. $76(10), 423-427$.

Wolf, P. de, 1964a. The distribution of barnacles on aged antifouling paints; consequences and a new hypothesis. - C. r. Congr. int. Corros. mar. Salisurres 1964, 381-387.

Wolf, P. de, 1964b. The problem of quality control in antifouling - J. Oil Colour Chem. Ass. 51, 944-960.

Wolf, P. de, 1973. Ecological observations on the mechanisms of dispersal of barnacle larvae during planktonic life and settling. Thesis, Univ. Groningen, $129 \mathrm{pp}$.

Wolf, P. de \& Lewis, W., 1972. A monitoring system for heavy metals along the Dutch coast. - TNO Nieuws $27,504-512$.

Wolf, P. de \& Londen, A. M. van, 1966. Antifouling compounds. - Nature, Lond. 209, 272-274.

Wolf, P. de, Kock, W. Chr. de \& Stam, A, 1972. Field experiments on the influence of copper and mercury in a natural musselbed. - TNO Nieuws 27, 497-504. 